\title{
Psychiatric Treatment Process of an Elderly Woman Patient Diagnosed with Anderson-Fabry Disease
}

Olgu Sunumu Case Report

\author{
Anderson-Fabry Hastalığı Tanılı Yaşlı Bir Kadın Hastanın \\ Psikiyatrik Tedavi Süreci
}

\section{Mehmet Hamdi Orum ๑}

\begin{abstract}
Anderson-Fabry disease (AFD) is a lysosomal storage disease characterized by accumulation of glycosphingolipids in all tissues and especially in the vascular endothelium. Kidney, heart, skin and eye are often affected organs. The nervous system and brain may also be affected primarily or secondarily, and AFD may present with psychiatric symptoms. Herein, we discussed a female patient with AFD who had severe psychiatric symptoms. The patient was managed by cognitive behavioral therapy plus psychotropic medications. The early detection of psychiatric disorders in patients with AFD may improve the quality of life and increase compliance to treatment.
\end{abstract}

Keywords: Fabry disease, depression, psychotherapeutic processes

öz

Anderson-Fabry hastalığı (AFD), tüm dokularda ve özellikle vasküler endotelde glikosfingolipidlerin birikmesi ile karakterize lizozomal bir depo hastalığıdır. Böbrek, kalp, cilt ve göz sıklıkla etkilenen organlardır. Sinir sistemi ve beyin de birincil veya AFD'ye ikincil olarak etkilenebilir ve AFD'de psikiyatrik semptomlar görülebilir. Bu olgu sunumunda, ciddi psikiyatrik belirtileri olan AFD'li bir kadınhastayı ele aldık. Hasta, bilişsel davranışçı terapi ve psikotropik ilaçlarla tedavi edildi. AFD hastalarında psikiyatrik bozuklukların erken tespiti yaşam kalitesini ve tedaviye uyumu artırabilir.

Anahtar kelimeler: Fabry hastalığı, depresyon, psikoterapötik süreçler

\section{INTRODUCTION}

Anderson-Fabry disease (AFD) is a $X$-linked recessive multisystem lysosomal storage disorder characterized by a deficient or lack of activity of lysosomal $\alpha$-galactosidase $A(\alpha-G L A)$. Accumulation occurs in lysosomes in numerous cells such as heart (cardiomyocytes and fibroblasts), capillaries (endothelial cells), kidneys (podocytes, tubular cells, glomerular endothelial cells, mesangial and interstitial cells), dorsal root ganglion neuron cells.Subsequently, intracellular dysfunction occurs and micro- vascular pathology is induced (1). Depending on the affected systems, various symptoms occur. Although kidney and cardiovascular system are the most frequently affected storage sites that increase mortality, nervous system involvement also affects the quality of life of the patients. Dysesthesia, temperature sensation deficits and paraesthesia may also occur. Headache, dizziness, vertigo, transient ischemic attack, ischemic stroke, behaviour disorders and dementia are among the cerebral findings ${ }^{(2)}$. In addition to the primary neuropsychiatric symptoms, the burden
(C) Telif hakkı TC. Să̆lkk Bakanlı̆̆ı İzmir Tepecik Eğit. ve Arast. Hastanesi. Logos Tip Yayınclık tarafindan yayınlanmaktadır. Bu dergide yayınlanan bütün makaleler Creative Commons Attf-GayriTicari 4.0 Uluslararası Lisansı ile lisanslanmıştr.

Cite as: Orum MH. Psychiatric treatment process of an elderly woman patient diagnosed with anderson-fabry disease. Tepecik Eğit. ve Araşt. Hast. Dergisi. 2021;31(1):110-3. 
of physical disease on many organs causes the occurrence of psychological problems and/or increased complaints ${ }^{(3)}$. In this case report, we discussed the psychiatric treatment process of a patient with AFD.

\section{CASE PRESENTATION}

A, a 75-year-old female patient was referred to us for complaints of reluctance, lack of pleasure, aggression and uneasiness. Depending on the AFD which was diagnosed with detection of heterozygote GLA mutation in genetic examination. The patient who had renal involvement for 22 years and had hemodialysis three times a week for 7 years, recently linked the death of a patient diagnosed with AFD in the dialysis centre to the medicines given by the doctors, so she did not want to use her drugs. The patient had been hospitalized in the internal medicine inpatient unit and had symptoms such as numbness, sweating, dizziness, low back pain, forgetfulness. She had cataract surgery and suffered twice from episodes of myocardial infarction (MI). Laboratory findings did not suggest the presence of any psychiatric features. Her medical history did not reveal any evidence of alcoholism, smoking or substance abuse. The following findings were obtained on various psychometric scales: Intelligence quotient was normal; Beck depression scale score was 34 (depressive); Beck anxiety scale score: 38 (anxious); Beck hopelessness scale score: 10 (yes)/10 (no) (pessimistic); body sensations scale score: 22 (somatic symptoms prominent); social relations sub-score of cognitive distortions scale: 49 (negative); personal achievements sub-score of cognitive distortions scale: 46 (negative); global assessment scale score: 31-40 range (some assessment of reality assessment or communication); anxiety severity scale score: 21 (concern evident); insight assessment scale score: 4 (partial insight); brief psychiatric rating scale score: 57 (impaired functionality);Maudsley obsessive-compulsive question list score: 16 (correct)/21 (wrong) (obsessive nature); automatic thoughts scale score: 70 (prominent cognitive errors); discomfort scale score: 19 (sensitive); from symptom checklist (SCL90-R) sub-parameters, somatization score: 1.58 (high), anxiety 1.5 (high), obsession 1.6 (high), depression 2.07 (high), interpersonal sensitivity 2.22 (high), psychotic symptom 1.6 (high), paranoid symptom 1.83 (high), anger 2.5 (high), phobic symptom 1.42 (high), additional score 2.14 (high), the overall symptom index was 1.82 (high). The Mini-Mental State Examination score of patient was 25. The patient was diagnosed with major depressive disorder (MDD) plus generalized anxiety disorder (GAD) according to the criteria of Diagnostic and Statistical Manual of Mental Disorders, $5^{\text {th }}$ Edition (DSM-5) ${ }^{(4)}$ and she was started on escitalopram $10 \mathrm{mg} /$ day and the dose of escitalopram was increased to $15 \mathrm{mg} /$ day and trifluoperazine ( $2 \mathrm{~m} /$ day) was started for her aggression. In the sixth month of the treatment, the patient's psychiatric symptoms were significantly reduced with escitalopram (15 mg/day), trifluoperazine ( $1 \mathrm{mg} /$ day) and cognitive behavioral therapy, and her compliance with the treatments used for physical and mental illnesses increased. At this stage, Beck depression scale score was 9 (normal) and Beck anxiety scale score was 38 (mild anxiety). The treatment of the patient's psychiatric findings increased her adherence to the treatment of other diseases. A written informed consent was obtained from the patient and her relatives.

\section{DISCUSSION}

In AFD, heterozygote female carriers have often been reported as being asymptomatic or having an attenuated form of the disease ${ }^{(5)}$. Female heterozygotes were erroneously described as "carriers of the defective gene" more or less safeguarded against developing disease manifestations and symptoms. Most female heterozygotes develop symptoms due to yet undetermined mechanisms and a high percentage of females develop vital organ involvement including the kidneys, heart and/or brain about a decade later than males ${ }^{(6)}$. 
The main effect of changes in the central nervous system in patients with AFD is pathological changes in blood flow to the brain which increases the incidence of stroke and transient ischemic attacks. White matter lesions are early and widespread findings in AFD that are well described in the literature. The relationship between chronic physical illnesses and psychiatric disorders has been frequently reported. Major depressive disorder (MDD), anxiety disorder (AD) and somatization disorder are the most frequently reported psychiatric disorders in chronic physical diseases ${ }^{(7)}$. In particular, there is a strong association between chronic pain and depression. As a chronic disease in which pain is a major feature, AFD would be expected to carry an increased risk of depression ${ }^{(8)}$. Psychiatric symptoms may occur due to medical treatment, and complications of AFD. For example, mood changes may develop as a result of a stroke and may have been a contributing etiologic factor in depression suffered by a AFD patient ${ }^{(9)}$. A patient with a history of $\mathrm{MI}$ associated with AFD may be accompanied by anxiety and panic disorders ${ }^{(3)}$. Cole et al. ${ }^{(8)}$ found the comorbidity of MDD in $46 \%$ of AFD patients. They stated that acroparaesthesiae, anhidrosis showed the largest odds of association with depression. Schermuly et al. ${ }^{(10)}$ reported that clinically relevant depressive syndromes were noted in $60 \%$ of the patients of AFD. AFD has been reported to produce a confused state and psychotic syndromes in rare cases ${ }^{(10)}$. Our case had depressive complaints and psychotic features. She was focused on body sensations. Her cognitive errors and automatic thoughts were highly prevalent. The patient was diagnosed with MDD and GAD according to DSM- 5 criteria, but psychotic findings did not meet any diagnostic criteria. The patient was evaluated as psychotic-featured MDD.It was thought that these psychiatric findings were directly related to the neurological involvement of the disease and/or indirectly due to the burden of physical illness.

Cognition refers to the complex processes such as language, problem solving and thinking which are generated by the methods and plans developed by processing the data coming from the senses and perceptions. The meaning of the event and the comments made about the event determine the reactions of the people. The dysfunctional beliefs in the cognitive structure shape the individual's thinking and lead to cognitive errors specific to psychopathology. Disasters, mind reading, always or never thinking of style, emotion deriving, over generalization are some of the cognitive errors. Cognitive behavioural therapy was was used for cognitive errors in our case. Pharmacological treatment was initiated for the depressive symptoms and psychotic nature of the patient. Concomitant use of cognitive configuration and drug therapy reduced the psychiatric symptoms in AFD and increased functionality ${ }^{(3,11)}$.

As a result, in addition to the debilitating physical symptoms of AFD, under-recognized/recognized psychiatric features may be present. AFD can present with various psychiatric manifestations. This study is important in terms of revealing possible psychiatric symptoms and suggesting targeted therapies in a person with AFD using various psychometric scales. In the light of available therapeutic options, early detection and adequate treatment of psychiatric disorders may improve the quality of life of the patients and patients' compliance with the treatment of diseases associated with other systems may be increased.

Conflict of Interest: There is no conflict of interest related to any person and / or institution.

Informed Consent: Informed consent was taken from the patient.

\section{REFERENCES}

1. Hagège A, Réant $P$, Habib G, Damy $T$, Barone-Rochette G, Soulat $\mathrm{G}$, et al. Fabry disease in cardiology practice: Literature review and expert point of view.Arch Cardiovasc Dis. 2019;112(4):278-87. [CrossRef]

2. Wanner C, Germain DP, Hilz MJ, Spada M, Falissard B, Elliott PM. Therapeutic goals in Fabry disease: Recommendations of a European expert panel, based on current clinical evi- 
dence with enzyme replacement therapy.Mol Genet Metab. 2019;126(3):210-1. [CrossRef]

3. Lelieveld IM, Böttcher A, Hennermann JB, Beck M, Fellgiebel A. Eight-year follow-up of neuropsychiatric symptoms and brain structural changes in Fabry disease.PLoS One. 2015;10(9):e0137603. [CrossRef]

4. American Psychiatric Association. Diagnostic and Statistical Manual of Mental Disorders, 5th ed.; Author: Washington, DC, 2013. [CrossRef]

5. Whybra C, Kampmann C, Willers I, Davies J, Winchester B, Kriegsmann J, et al. Anderson-Fabry disease: clinical manifestations of disease in female heterozygotes. J Inherit Metab Dis. 2001;24(7):715-24. [CrossRef]

6. Germain DP. Fabry disease. Orphanet J Rare Dis. 2010;5:30. [CrossRef]

7. Boland RJ, Rundell J, Epstein S, Gitlin D. Consultation-liaison psychiatry vs psychosomatic medicine: what's in a name?Psychosomatics. 2018;59(3):207-10. [CrossRef]

8. Cole AL, Lee PJ, Hughes DA, Deegan PB, Waldek S, Lachmann RH. Depression in adults withFabry disease: a common and under-diagnosed problem. J Inherit Metab Dis. 2007;30(6):943-51. [CrossRef]

9. Grewal RP. Psychiatric disorders in patients with Fabry's disease. Int J Psychiatry Med. 1993;23(3):307-12. [CrossRef]

10. Schermuly I, Müller MJ, Müller KM, Albrecht J, Keller I, Yakushev I, et al. Neuropsychiatric symptoms and brain structural alterations in Fabry disease. Eur J Neurol. 2011;18(2):347-53. [CrossRef]

11. Örüm MH, Kara $M Z$, Kuştepe A, Kalenderoğlu A. Bilişselhatalarvedikkat-eksikliği hiperaktivite bozukluğubelirt ilerininmaddekullanımözellikleriileilişkisi. BağımlılıkDergisiJournal of Dependence. 2019;20(2):47-60. 